\title{
Suppression of Post-Flashover Compartment \\ Fires Using Manually Applied Water Sprays
}

David W. Stroup

David D. Evans
Prepared for:

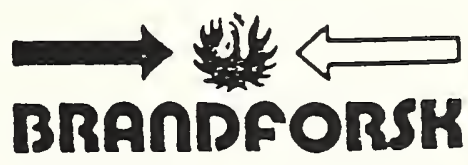

Brandforsk

Swedish Fire Research Board

S-115 87 Stockholm

Sweden

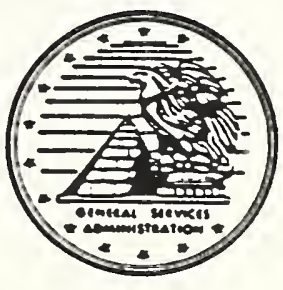

General Services Administration

Public Buildings Service

Office of Real Property Management and Safety

Washington, DC 20405

\#4625

institute of Standards and Technology und Fire Research Laboratory

urg, MD 20899 



\section{Suppression of Post-Flashover Compartment Fires Using Manually Applied Water Sprays}

David W. Stroup

David D. Evans

July 1991

Prcpared for:

BRANDFORSK

Vilhelm Sjölin, Executive Director

Swedish Fire Research Board

S-115 87 Stockholm

Sweden

U.S. Department of Commerce

Robert A. Mosbacher, Secretary

National Institute of Standards and Technology

John W. Lyons, Dircctor

Building and Fire Research Laboratory

Gaithersburg, MD 20899
General Services Administration Richard G. Austin, Administrator Public Buildings Service William C. Coleman, Commissioner Office of Real Property Management and Safety Washington, DC 20405 

Page

List of Tables . . . . . . . . . . . . . . . iv

List of figures . . . . . . . . . . . . . . . . v

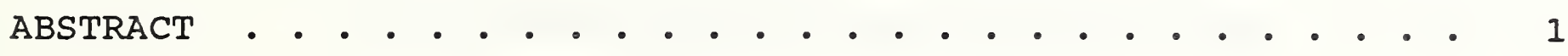

1. INTRODUCTION . . . . . . . . . . . . . . . . . 2

2. DESCRIPTION OF THE TEST FACILITY . . . . . . . . . . . . 3

2.1 Details of the Room and Corridor Configuration . . . 3

2.2 Instrumentation and Data Acquisition . . . . . . . 4

3. TEST DESCRIPTIONS . . . . . . . . . . . . . . . 5

3.1 Full Scale Tests . . . . . . . . . . . . . . 5

3.2 Nozzle Drop Size Tests.... . . . . . . . 6

4. TEST RESULTS AND DISCUSSION . . . . . . . . . . . 7

5. CONCLUSIONS . . . . . . . . . . . . . . . 9

6. ACKNOWLEDGEMENTS . . . . . . . . . . . . . . . . 9

7. REFERENCES . . . . . . . . . . . . . . 10 
Page

Table 1. Location of Instrumentation . . . . . . . . . .

Table 2. Summary of Fuel and compartment Parameters . . .

Table 3. Nozzle Parameters for Test Series . . . . . . . .

Table 4. Event Chronology for the First Test . . . . . . . . 14

Table 5. Event Chronology for the second Test . . . . . . . 14

Table 6. Event Chronology for the Third Test . . . . . . . . 14

Table 7. Event Chronology for the Fourth Test . . . . . . 14

Table 8. Crib Weights - Before and After Test . . . . . . 15

Table 9. Maximum Heat Release Rate . . . . . . . . . . . 15

Table 10. Maximum and Minimum Average Burn Room Gas Temperatures . . . . . . . . . . . . . .

Table 11. Maximum and Minimum Average Interior Wall Surface Temperatures 


\section{List of Figures}

Page

Figure 1. Overall Test Layout (dimensions in meters) . .

Figure 2 . Detailed Burn Room Diagram including Instrument Locations.

Figure 3. Diagram of Wood Crib used in Test Series . . . 19

Figure 4. Diagram of Crib Placement in Burn Room . . . . 20

Figure 5 . Aspirated Thermocouple Probe Tip . . . . . . 21

Figure 6. Photograph of burn room at point of full involvement

Figure 7. Photograph of firefighter attempting to extinguish fire . . . . . . . . . . . . . .

Figure 8 .

Water Spray Drop Size Analysis, Flow Rate $=36.5 \mathrm{l} / \mathrm{min}$

Figure 9 .

Water Spray Drop Size Analysis, Flow Rate $=16.3 \mathrm{l} / \mathrm{min}$

Figure 10.

Water Spray Drop Size Analysis, Flow

Figure 11. Rate $=79 \mathrm{l} / \mathrm{min}$

Figure 12 . Graph of Heat Release Rates for All Tests

Burn Room Gas Concentrations for the First Test 28

Figure 13. Burn Room Gas Temperatures Profiles for the First Test (Bare Bead) . .

Figure 14. Burn Room Gas Temperatures Profiles for First Test (Aspirated) . . . . . . . . . . . 30

Figure 15. Burn Room Average Gas and Wall Temperatures for the First Test . . . . . . . . . . . . . .

Figure 16. Burn Room Average Gas and Wall Temperatures for the Second Test . . . . . . . . . . . .

Figure 17. Burn Room Average Gas and Wall Temperatures for the Third Test. . . . . . . . . . . . .

Figure 18. Burn Room Average Gas and Wall Temperatures for the Fourth Test 



\title{
SUPPRESSION OF POST-FLASHOVER COMPARTMENT FIRES
} USING MANUALLY APPLIED WATER SPRAYS

\author{
David W. Stroup* \\ David D. Evans
}

\begin{abstract}
A series of four full scale fire tests were conducted to measure the effect of manual fire fighting efforts on post-flashover room fires. One objective of these tests was to generate data for evaluation of computer models of the fire suppression process. The tests were conducted in a room and corridor configuration consisting of a $2.44 \mathrm{~m}$ cube burn room connected to a $12.8 \mathrm{~m}$ long, $2.44 \mathrm{~m}$ wide, and $2.44 \mathrm{~m}$ high corridor. Hose nozzles with different water spray flow rates and median drop sizes were used in each of the four nominally identical wood crib fires. Gas temperatures, wall surface temperatures and concentrations of oxygen, carbon dioxide, and carbon monoxide were measured in the burn room. specialized aspirated and shielded thermocouples were used to minimize the effects of the water sprays on gas temperature measurements. This study showed that a water spray flow of 36.5 $\ell / m i n$ with volume median drop size of 930 microns was just able to control the post-flashover fire, the flow of $16.3 \mathrm{l} / \mathrm{min}$ with volume median drop size of 800 microns did not control the fire, while the $79 \mathrm{l} / \mathrm{min}$ flow with volume median drop size of 1040 microns definitely extinguished the fire.
\end{abstract}

Key words: crib tests; drop size measurements; extinguishment; fire fighting; fire fighting equipment; fire suppression; flashover; nozzles; room fires; sprinkler systems; water sprays.

*presently with the General Services Administration 


\section{INTRODUCTION}

Water is the usual agent of choice for suppressing unwanted fires. It is used in both automatic sprinkler systems and manual fire fighting. However, the lack of a quantitative understanding of the fire suppression process prevents engineering analysis of these fire fighting systems. Due in part to the high cost and the difficulty associated with making accurate measurements during the suppression process, very few full scale fire tests which include measurements during fire suppression efforts have been conducted. A review of available experimental studies of fire suppression in compartments has been performed by Pietrzak [1] ${ }^{1}$.

As part of an effort to determine the level of fire protection required for areas exposed to the effects of post-flashover room fires, the center for Fire Research (CFR) (now part of the Building and Fire Research Laboratory) at the National Institute of Standards and Technology conducted a series of full-scale fire tests for the General services Administration [2]. These tests were carried out in a fire resistant structure representing a portion of a building room-corridor system. The test series involved exposure of the corridor and a target room to a fully developed (post-flashover) room fire. The fully involved room fire was allowed to burn for approximately ten minutes while measurements of corridor and target room conditions were recorded to satisfy General Services Administration (GSA) objectives. At the end of this time, manual fire suppression using fire fighting water hose streams was started and measurements were made of room conditions. This latter fire suppression phase of the experiments is discussed in this report.

There was a special effort made to assure that the data generated from these tests could be used to evaluate capabilities of the Fire Demand Model [3]. The Fire Demand Model is a one zone model, which simulates suppression of post-flashover fires in a single compartment. The Fire Demand Model uses average gas and wall surface temperatures to determine fire control during manual suppression. This report documents room fire conditions during fire suppression to facilitate comparisons with the Fire Demand Model as well as any other model of manual fire suppression that may be developed in the future. Detailed comparisons of Fire Demand Model predictions with the data presented in this report are contained in a separate report [4].

A complete discussion of the Fire Demand Model is beyond the scope of this report. However, a brief description of the required input data and calculated model outputs is essential. Information related to the compartment geometry (room dimensions, wall/ceiling

1 Numbers in brackets refer to references listed at the end of this report. 
materials, vent dimensions, and vent locations), fuel (amount, surface area, charring or noncharring, and exposed surface), and water application (delivery rate, nozzle pressure, cone angle, sweep time, volume median drop diameter, and location of nozzle) are needed to use the model successfully. The model calculates the temperature histories of the compartment gas and wall/ceiling surfaces. Based on specified criteria and the calculated temperature histories, the model determines whether or not fire knockdown is achieved and provides information on total water used, total water vaporized and unvaporized, and total fuel remaining at knockdown.

In order to assure the usefulness of the data, the Fire Demand Model was used during the planning process to select combinations of hose nozzle drop size and flow used in each test. Based on these calculations, three flows were selected for use in suppressing the fires. The flows were selected to definitely control the fire, definitely not control the fire, and just control the fire according to calculations.

\section{DESCRIPTION OF THE TEST FACILITY}

\subsection{Details of the Room and corridor Configuration}

The plan view of the overall test structure, consisting of a "burn room" containing the fire source, a "target room" and a corridor connecting the two rooms, is shown in Figure 1. The "burn room" was nominally a $2.44 \mathrm{~m}(8 \mathrm{ft})$ cube. The burn room was lined with $25.4 \mathrm{~mm}$ ( $1 \mathrm{in}$ ) thick calcium silicate board. The lining was constructed using two layers of $1.22 \mathrm{~m}(4 \mathrm{ft}$ ) by $2.44 \mathrm{~m}$ ( $8 \mathrm{ft}$ ) sheets for each side. To minimize air leakage, the layers were overlaid so that the seam for the first layer ran perpendicular to the seam for the second layer. Details of the burn room, including instrument types and locations, are shown in Figure 2.

The burn room was provided with two door openings. The opening between the burn room and the exhaust hood was $0.76 \mathrm{~m}(2.5 \mathrm{ft})$ wide by $1.52 \mathrm{~m} \mathrm{(5} \mathrm{ft)} \mathrm{high.} \mathrm{The} \mathrm{other} \mathrm{opening,} \mathrm{between} \mathrm{the} \mathrm{burn} \mathrm{room}$

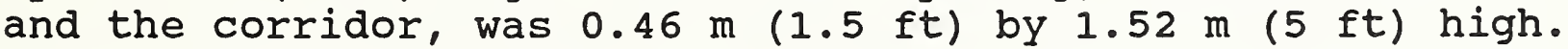
Initial measurements in the corridor and target room during fire growth and fully involved room fire exposures are contained in the report to the General Services Administration [2]. After completing measurement of corridor and target room conditions, the suppression test was started. In order to simplify comparison of test data to the Fire Demand Model [3], the burn room was altered to have only one ventilation opening for the suppression phase of the experiment. This was accomplished by closing the opening between the burn room and the corridor using a sliding piece of calcium silicate board prior to initiating suppression in the first, second, and third tests. In the last (fourth) test, this 
opening was sealed for the entire test, both fire growth and suppression phases.

Wood cribs were used as the fuel source in these tests. Cribs can be constructed to provide a wide variety of burning rates and, once fully ignited, provide a steady heat release rate for a long period of time. Cribs contain both exposed and shielded surfaces and are generally not easy to extinguish.

This study required that the fuel reach and maintain a near steady burning rate for more than ten minutes. The fuel array chosen consisted of nine cribs arranged in three rows of three cribs each $0.6 \mathrm{~m}$ (2 ft) $\times 0.6 \mathrm{~m}(2 \mathrm{ft}) \times 0.3 \mathrm{~m}(1 \mathrm{ft})$ high. Figure 3 is representative of the individual test crib construction. Each crib consisted of 48 sticks of Douglas fir arranged in eight layers of six sticks each. Each stick had nominal dimensions of $0.04 \mathrm{~m}$ ( 1.5 in) $\times 0.04 \mathrm{~m}(1.5 \mathrm{in}) \times 0.6 \mathrm{~m}(2 \mathrm{ft})$ long. The nominal mass of each crib was $21.5 \mathrm{~kg}$ ( $47 \mathrm{lbs}$ ) with a moisture content between 5 and 10 percent.

For each test, the array was positioned in the center of the burn room (Figure 4). Each crib was elevated approximately $0.13 \mathrm{~m}$ ( 5 in) above the floor. The cribs were ignited using pans of heptane centered under each row of three cribs. Each pan contained approximately $1.25 \ell(0.33 \mathrm{gal})$ of heptane which burned for about two minutes. This technique provided for uniform ignition of all of the cribs.

\subsection{Instrumentation and Data Acquisition}

Measurements during the fire suppression tests were taken in the burn room and the test facility exhaust stack. The general locations of the various measurement devices in the burn room are shown in Figure 2. Their placement and distribution is summarized in Table 1. Two thermocouple arrays were located in the burn room. one array was made up of $0.5 \mathrm{~mm}(20 \mathrm{mil})$ chromel-alumel wire insulated with glass braid. The other thermocouple array was made up of aspirated thermocouples. Aspirated probes were used to reduce the influence of radiation and water spray on measured gas temperatures.

Ordinary, aspirated probes consist of a thermocouple bead placed inside a straight, constant internal diameter tube [5]. With a tube gas flow velocity of $7 \mathrm{~m} / \mathrm{s}(21 \mathrm{ft} / \mathrm{s})$, this type of probe has been found to draw water spray into the tube [6]. To minimize this effect, a flared tube tip, used in a previous set of water spray fire suppression tests [6], was also used in this study. The design of the tip of the aspirated probe is shown in Figure 5 . The large diameter at the open end of the probe tip resulted in a low velocity which eliminated the drawing of large water droplets into the tube. The small diameter around the thermocouple produced the 
high $7 \mathrm{~m} / \mathrm{s}(21 \mathrm{ft} / \mathrm{s})$ gas flow velocity, increasing the convective heat transfer to the thermocouple bead and thereby reducing radiation effects. The final probe design included a ceramic tube to anchor the thermocouple bead in the aspirated probe tip. In addition, the probes were installed angled downward to further minimize the entry of water into the tubes and provide drainage for any that does.

A gas sampling tube was located $0.9 \mathrm{~m}$ (3 ft) below the ceiling adjacent to the two thermocouple arrays. Gases sampled through this horizontal $9.4 \mathrm{~mm}$ ( $3 / 8 \mathrm{in}$ ) I.D. stainless steel tube were analyzed for oxygen, carbon dioxide, and carbon monoxide content. The tube was connected outside the burn room to polyethylene tubing which routed the gas samples first through a moisture condenser trap and then through the gas analyzers in series.

Interior and exterior surface temperatures of both walls without openings (north and south, see Figure 2) in the burn room were measured using $0.5 \mathrm{~mm}(20 \mathrm{mil})$ chromel-alumel wire. The thermocouples in the north wall were placed at locations corresponding to the gas thermocouple positions. The south wall thermocouples were located at intermediate locations to check the symmetry of the burn room wall temperatures.

Temperatures, velocities, and oxygen, carbon dioxide, and carbon monoxide concentrations in the gases in the test facility exhaust stack were monitored. These data were used to determine the mass flow through the stack and the total rate of heat production by the method of oxygen consumption calorimetry [7].

The measurements obtained from the various instruments were recorded at a rate of one scan every eleven seconds on a computerized data acquisition system.

\section{TEST DESCRIPTIONS}

\subsection{Full scale Tests}

Immediately prior to the test, the cribs were weighed and their moisture content checked. The initial crib weights and their placement in the burn room are presented in Table 2 and Figure 4 respectively. The cribs were placed on bricks in the burn compartment and the trays were filled with heptane. After the data acquisition system was started and its proper functioning verified, the heptane was ignited. Typically, the fire reached flashover within about two minutes after ignition. A photograph illustrating flashover is shown in Figure 6 . The post-flashover fire was allowed to burn for nominally ten minutes with a typical heat release rate of 1 megawatt. At this point, data collection for the first phase of the experiment was completed and the sliding door between the burn room and the corridor was closed (except for the 
fourth test). The temperatures in the burn room, as indicated by the bare bead thermocouple array, were allowed to stabilize

(approximately one minute). Once the burn room temperature profile stabilized at a nearly uniform value, the suppression efforts were initiated.

A trained fire fighter, wearing protective gear (Figure 7), applied water into the compartment through the burn room to exhaust hood doorway opening (west wall), Figure 2. The fire fighter used a commercial fire fighting nozzle. The variable spray pattern nozzle and water supply had been adjusted prior to the test to duplicate previous settings for which drop size distributions and flow rates were measured. The compartment and nozzle parameters are summarized in Tables 2 and 3 for each of the four tests. Test chronologies are listed in Tables 4-7. The nozzle was attached

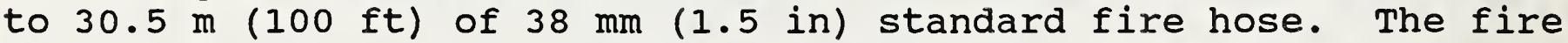
fighter intentionally stirred the air in the compartment by spraying water around the room with a circular sweeping motion of the hose nozzle. The fire fighter's movement of the nozzle was monitored to assure a compartment sweep time of approximately one second ${ }^{2}$. After one to two minutes of water application at the specified flow, measurements were completed. The fire was extinguished as quickly as possible to allow for measurement of residual crib weight after drying for several days under normal laboratory conditions $\left(22^{\circ} \mathrm{C}, 50 \%\right.$ R.H.). Residual crib weights are shown in Table 8 for the first and second tests. Residual crib weights were not measured in the third and fourth tests.

\subsection{Nozzle Drop Size Tests}

Droplet size distributions were obtained for two different hose nozzles by catching the spray and digitally counting and sizing the droplets. Specifically, a glass petri dish, containing castor oil, was used to collect the water droplet samples from the interior of the water spray pattern emitted from a test hose nozzle. The hose nozzle, set at the proper flow and cone angle, was opened and allowed to flow water. Droplets were allowed to collect in the oil for about one second, and then the cover was placed on the petri dish. Droplets in the dish were sized and counted using a video image analysis system following ASTM E 799-81, "Standard Practice for Data Criteria and Processing for Liquid Drop Size Analysis" [9]. This system could resolve and count droplets as small as 126 microns. Droplet sizing and counting were completed prior to any droplet agglomeration.

Ten samples of the spray from one commercial fire nozzle flowing $36.5 \mathrm{l} / \mathrm{min}(9.6 \mathrm{gpm})$ at a nozzle pressure of $584 \mathrm{kPa}$ (85 psi) were

\footnotetext{
${ }^{2}$ The sweep time is a parameter used in the Fire Demand Model [3]
} 
analyzed. This nozzle and flow rate were used for fire suppression in the first and second tests. Cumulative number and volume distributions against droplet diameter are shown in Figure 8 . The smallest drop recorded in the measurements had a diameter of 160 microns while the largest had a diameter of $2690 \mathrm{microns}$. Based on this series of tests, which sampled 40279 drops, the volume median drop diameter for the spray was determined to be 930 microns.

This first nozzle was damaged during the second test; therefore, a new nozzle was used for the third and fourth tests. Ten samples were collected with this nozzle operating at a flow rate of $16.3 \mathrm{l} / \mathrm{min}(4.3 \mathrm{gpm})$ and nozzle pressure of $584 \mathrm{kPa}$ (85 psi). Eight samples were taken at a flow of $79 \mathrm{l} / \mathrm{min}(20.5 \mathrm{gpm})$. These flow rates were used for the third and fourth tests, respectively. The cumulative spray distributions for the spray measurements at the two flow rates are presented in Figures 9 and 10 , respectively. In addition to general parameters related to the nozzle settings, Table 3 presents a summary of the nozzle flow rates and volume median droplet diameters used for each test.

For the lower flow (used in the third test), the smallest drop recorded in the measurements had a diameter of 160 microns while the largest had a diameter of 2550 microns. Based on this series of tests, which sampled 23184 drops, the volume median drop

diameter for the nozzle was determined to be $800 \mathrm{microns}$. At the higher flow (used in the fourth test), the smallest drop recorded in the measurements had a diameter of 150 microns while the largest had a diameter of 4250 microns. Based on this series of tests which sampled 26481 drops, the volume median drop diameter for the nozzle was determined to be 1040 microns.

\section{TEST RESULTS AND DISCUSSION}

Figure 11 presents the heat release rate data for the four tests as determined from oxygen depletion measurements. Peak heat release rates of between 1.8 and $2.6 \mathrm{MW}$ were obtained for all of the tests. Table 9 lists the peak heat release rate for each of the four tests. With the exception of the last test, the heat release rate remained at or above 1.5 MW for eight minutes prior to the start of manual fire suppression. No corridor or target room measurements were taken during the last test. The opening between the burn room and the corridor was sealed prior to the start of the test. Therefore, the total duration of the last test was less than the other three tests. From the heat release rate graphs, it can readily be seen that "flashover" occurred very quickly (within about two minutes after ignition). The peak visible at about 800 seconds in Figure 11 (dotted line) is the result of failure of the water spray to control the fire in the third test. At the specified flow, the hose stream was having a minimal effect on the fire. When the flow was stopped, the fire heat release rate 
immediately began to increase. This indicates that little, if any, water was penetrating to the wood crib fuel source.

Figure 12 shows the measured concentrations of oxygen, carbon dioxide, and carbon monoxide inside the burn room for the first test. These data are typical of that measured during each test. During one test, the oxygen content in the out flowing gases was measured. After "flashover" and for the duration of the test (until extinguishment), there was no measurable oxygen remaining in the gases leaving the burn room. This indicates that for a majority of the time prior to initiation of the fire suppression efforts, the fire in the compartment was ventilation limited.

The gas temperatures measured in the burn room at various distances below the ceiling during the first test are plotted in Figure 13 as a function of time. It can readily be seen that after flashover the gas temperature is almost constant throughout the room. This indicates that the compartment gas is "well-stirred" as required by the Fire Demand Model [3]. The two thermocouples located closest to the floor sometimes lag the overall compartment temperature. This is due to the fact that they are located below the top level of the cribs and outside of the bulk of the fire. Figure 14 presents the gas temperatures as measured by the aspirated thermocouples. Again, the measured temperatures are quite uniform throughout the compartment during a majority of the burn.

The average burn room gas temperatures, both bare bead and aspirated thermocouple readings, and average interior and exterior wall temperatures are plotted as a function of time in Figures 15, 16, 17, and 18 for the four tests. The average gas temperatures and average interior wall surface temperatures are needed to evaluate the performance of the Fire Demand Model.

The average burn room gas temperature for all the tests was about $800^{\circ} \mathrm{C}$ (bare bead thermocouples). The aspirated thermocouples indicated average burn room gas temperatures 50 to 200 degrees less than corresponding bare bead thermocouple readings. This difference is due primarily to the radiation effects associated with the bare bead thermocouples. The average maximum and minimum burn room gas temperatures are summarized in Table 10 for all of the tests. These values were determined by calculating the arithmetic averages for each set of thermocouples (bare bead, aspirated, gas, or wall) in the burn room. Thermocouples below the height of the burning cribs were excluded from the averages. The minimum values are those measured during active manual fire fighting.

Figures 15 through 18 show the average measured interior and exterior wall surface temperatures for the four tests. Peak wall surface temperatures of between $600^{\circ} \mathrm{C}$ to $700^{\circ} \mathrm{C}$ were measured. Peak temperatures on the exterior wall surface were determined to be approximately $80^{\circ} \mathrm{C}$. The maximum and minimum average burn room 
interior wall surface temperatures are summarized in Table 11 for all of the tests. The minimum values are those measured during active manual fire fighting.

\section{CONCLUSIONS}

A series of four room fire tests were conducted in a room and corridor test facility. The fires were allowed to grow to flashover and remain there for approximately 10 minutes. Each fire was extinguished in a manner designed to simulate the action of fire fighters. The data generated during this test series can be used to validate partially the calculations contained in the Fire Demand Model.

As determined by visual observation of the tests; the water spray flow of $36.5 \mathrm{l} / \mathrm{min}$ with volume median drop size of 930 microns was just able to control the fire, the flow of $16.3 \mathrm{l} / \mathrm{min}$ with volume median drop size of 800 microns did not control the fire, while the $79 \mathrm{l} / \mathrm{min}$ flow with volume median drop size of 1040 microns definitely extinguished the fire. Detailed comparisons of predictions including comparisons of measured and predicted gas temperatures and wall surface temperatures and fuel consumption using the Fire Demand Model are contained in a companion report being prepared by Mission Research Corporation [4].

\section{ACKNOWLEDGEMENTS}

Appreciation is extended to $V$. Sjolin of Brandforsk, the Swedish Fire Research Board, for his interest in these studies and to D. Bathurst and D. Frable of the General Services Administration for their support and cooperation in this joint study. In addition, the authors would like to thank D. Madrzykowski, R. McLane and R. Zile of the Building and Fire Research Laboratory for their assistance in setting up and conducting these tests. Special appreciation is extended to $\mathrm{J}$. Dieter of the NIST Fire Department and J. McElroy, R. Vettori, and G. Roadarmel of BFRL who carried out the extinguishment part of this project. The assistance provided by $\mathrm{J}$. Lawson and $\mathrm{J}$. Didion of BFRL in conducting the nozzle spray drop size distribution measurements is greatly appreciated. Finally, the authors are grateful to $L$. Pietrzak of Mission Research Corporation for providing the Fire Demand Model analysis used to plan the test series. 


\section{REFERENCES}

1. Pietrzak, L. M., "A Physically Based Fire Suppression Computer Simulation - Definition, Feasibility Assessment, Development Plan, and Application," Report MRC-R-732, Mission Research Corporation, Santa Barbara, California; April 1983.

2. Stroup, D. W. and Madrzykowski, D., "Conditions in Corridors and Adjoining Areas Exposed to Post-Flashover Room Fires," to be published.

3. Pietrzak, L. M., Johnson, G. A., and J. Ball, "A Physically Based Fire Suppression Computer Simulation for Post-Flashover Compartment Fires," Mission Research Corporation, Santa Barbara, California; June 1984 .

4. Pietrzak, L. M., and Dale, J. J., "Comparison of PostFlashover Compartment Fire Suppression Tests to Fire Demand Model Predictions," MRC R-1343, Mission Research Corporation, Santa Barbara, California; March 1991.

5. Newman, J. S. and Croce, P. A., "A Simple Aspirated Thermocouple for Use in Fires," Journal of Fire and Flammability, Vol. 10 (October 1979), p.326.

6. Milke, J., Evans, D., and W. Hayes, Jr., Water Spray Suppression of Fully Developed Wood Crib Fires in a Compartment, National Bureau of Standards (U.S.) Report of Test FR 3956; January 1985.

7. Huggett, C., "Estimation of Rate of Heat Release by Means of Oxygen Consumption Measurements," Fire and Materials; Vol. 4, No. 2, 61-65, June 1980 .

8. Parker, W. J., Calculations of the Heat Release Rate by oxygen Consumption for Various Applications, National Bureau of Standards (U.S.) NBSIR 81-2427-1; March 1982.

9. American Society for Testing and Materials, "Standard Practice for Data Criteria and Processing for Liquid Drop Size Analysis," E 799, ASTM, 1981. 
Table 1. Location of Instrumentation

\section{FIRE SUPPRESSION TEST SERIES}

I. Instrumentation in the Burn Room, Corridor, and Target Room

A. Thermocouple Arrays, Gas Temperature

Array 1 in burn room, Northwest quadrant - 9

thermocouples at $0.26,0.66,1.07,1.47,1.88,2.19$, $2.34,2.39$, and $2.44 \mathrm{~m}$ from floor.

Array 2 in burn room, Northwest quadrant - 7 aspirated thermocouples at $0.66,1.07,1.47,1.88,2.19,2.34$, and $2.39 \mathrm{~m}$ from floor.

B. Burn room wall thermocouples

North wall, interior - 8 thermocouples at $0.26,0.66$, $1.07,1.47,1.88,2.19,2.34$, and $2.39 \mathrm{~m}$ from floor.

North wall, exterior - 8 thermocouples at $0.26,0.66$, $1.07,1.47,1.88,2.19,2.34$, and $2.39 \mathrm{~m}$ from floor.

South wall, interior - 3 thermocouples at $1.07,1.88$, and $2.34 \mathrm{~m}$ from floor.

South wall, exterior - 3 thermocouples at $1.07,1.88$, and $2.34 \mathrm{~m}$ from floor.

\section{Gas Analysis}

Burn room probe, $0.46 \mathrm{~m}$ horizontally from the Northwest corner, $1.53 \mathrm{~m}$ from the floor - oxygen, carbon dioxide, and carbon monoxide concentrations.

II. Exhaust Hood

1 smoke meter

1 probe for sampling oxygen, carbon dioxide, and carbon monoxide.

9 pitot static probes.

9 thermocouples. 
Table 2. Summary of Fuel and Compartment Parameters

$$
\begin{aligned}
& \text { Burn Room Dimensions: Length }=2.44 \mathrm{~m} \\
& \text { width }=2.44 \mathrm{~m} \\
& \text { Height }=2.44 \mathrm{~m}
\end{aligned}
$$

Wall Lining: Material - Calcium silicate board

$$
\begin{array}{ll}
\text { Thickness } & =0.0254 \mathrm{~m} \\
\text { Density } & =700 \mathrm{~kg} / \mathrm{m}^{3} \\
\text { Specific Heat } & =0.3 \mathrm{kcal} / \mathrm{kg} /{ }^{\circ} \mathrm{C} \\
\text { Thermal Conductivity } & =1.72 \times 10^{-3} \mathrm{kcal} / \mathrm{m} / \mathrm{min} /{ }^{\circ} \mathrm{C}
\end{array}
$$

Vent to Corridor: Height $=1.52 \mathrm{~m}$

$$
\text { Width }=0.46 \mathrm{~m}
$$

Distance to Top of Vent $=1.52 \mathrm{~m}$ (from floor)

This vent was closed approximately 2 minutes prior to the initiation of suppression activities (first, second, and third tests). This vent was sealed prior to the start of the last (fourth) test.

Vent to Hood: Height $=1.52 \mathrm{~m}$

Width $=0.76 \mathrm{~m}$

Distance to Top of Vent $=1.52 \mathrm{~m}$ (from floor)

Fuel Load: 9 Douglas fir wood cribs

cribs were distributed in a 3 by 3 matrix centered in the room.

Total weight $=184 \mathrm{~kg}$ or $21.5 \mathrm{~kg} / \mathrm{crib}$

Extinguishable Fuel Fraction $=16 \%$ to $25 \%$ (from dyed water tests) 
Table 3. Nozzle Parameters for Test Series

Two hose nozzles were used for this test series. The first was used for the first and second tests. The second was used for the third and fourth tests. Sweep Time $=1 \mathrm{~s}$ Cone Angle $=60^{\circ}$ Nozzle Pressure $=584 \mathrm{kPa}$ Location of Nozzle: Burn Room Doorway, West Wall

\section{First Test}

Nozzle Flow Rate $=36.5$ liters $/ \mathrm{min}$

Volume Median Drop Size $=930$ microns

\section{Second Test}

Nozzle Flow Rate $=36.5$ liters $/ \mathrm{min}$

Volume Median Drop Size $=930 \mathrm{microns}$

\section{Third Test}

Nozzle Flow Rate $=16.3$ liters $/ \mathrm{min}$

Volume Median Drop Size $=800$ microns

\section{Fourth Test}

Nozzle Flow Rate $=79.0$ liters $/ \mathrm{min}$

Volume Median Drop Size $=1040$ microns

Nozzle (1)

BURN

ROOM

CORRIDOR 
Table 4. Event Chronology for the First Test

$\frac{\text { Time }}{0}$
70
200
500
561
670
683

\begin{tabular}{l} 
Event \\
\hline Ignition \\
Full room involvement \\
Peak heat release rate \\
Burn room-corridor door closed \\
Initiation of fire suppression test \\
End of fire suppression test \\
Fire extinguished
\end{tabular}

Table 5. Event Chronology for the Second Test

$\frac{\text { Time }}{0}$
74
150
400
500
550
740
740

\section{Event}

Ignition

Full room involvement Peak heat release rate

Target room pressurization turned off Burn room-corridor door closed Initiation of fire suppression test End of fire suppression test Fire extinguished

Table 6. Event Chronology for the Third Test

Time

0

90

200

575

650

699

711
Event

Ignition

Full room involvement

Peak heat release rate

Burn room-corridor door closed

Initiation of fire suppression test End of fire suppression test Fire extinguished

Table 7. Event Chronology for the Fourth Test

$\frac{\text { Time }}{0}$

85

178

353

475

600
Event

Ignition

Full room involvement

Peak heat release rate

Initiation of fire suppression test End of fire suppression test

Fire extinguished 
Table 8. Crib Weights - Before and After Test

\begin{tabular}{||c|c|c|}
\hline \multirow{2}{*}{ Test } & \multicolumn{2}{|c|}{ Weight (kg) } \\
\cline { 2 - 3 } & Before Test & After Test \\
\hline \hline First & 196 & 129 \\
\hline Second & 189 & 129 \\
\hline Third & 188 & * \\
\hline Fourth & 173 & $*$ \\
\hline
\end{tabular}

* not measured

Table 9. Maximum Heat Release Rate

\begin{tabular}{|c|c|}
\hline Test & $\begin{array}{c}\text { Maximum Heat } \\
\text { Release Rate } \\
\text { (MW) }\end{array}$ \\
\hline First & 2.2 \\
\hline Second & 1.8 \\
\hline Third & 2.3 \\
\hline Fourth & 2.6 \\
\hline
\end{tabular}


Table 10. Maximum and Minimum Average Burn Room Gas Temperatures

\begin{tabular}{|c|c|c|c|c|}
\hline Test & \multicolumn{2}{|c|}{$\begin{array}{c}\text { Maximum Temperature } \\
\left({ }^{\circ} \mathrm{C}\right)^{*}\end{array}$} & \multicolumn{2}{|c|}{$\begin{array}{l}\text { Minimum Temperature } \\
\left({ }^{\circ} \mathrm{C}\right)^{* *}\end{array}$} \\
\hline $\begin{array}{l}\text { (Thermo- } \\
\text { couple } \\
\text { Type) }\end{array}$ & Bare Bead & Aspirated & Bare Bead & Aspirated \\
\hline First & 850 & 750 & 25 & 100 \\
\hline Second & 850 & 700 & 30 & 200 \\
\hline Third & 850 & 800 & 200 & 450 \\
\hline Fourth & 775 & 700 & 100 & 250 \\
\hline
\end{tabular}

* Rounded to nearest 25 degrees

** Rounded to nearest 5 degrees

Table 11. Maximum and Minimum Average Interior Wall Surface Temperatures (Bare Bead Thermocouples)

\begin{tabular}{|c|c|c|}
\hline Test & Maximum Temperature & $\begin{array}{c}\text { Minimum Temperature } \\
\left.\left({ }^{\circ} \mathrm{C}\right)^{*}\right)^{* *}\end{array}$ \\
\hline First & 700 & 30 \\
\hline Second & 800 & 75 \\
\hline Third & 750 & 100 \\
\hline Fourth & 650 & 100 \\
\hline
\end{tabular}

* Rounded to nearest 25 degrees

** Rounded to nearest 5 degrees 


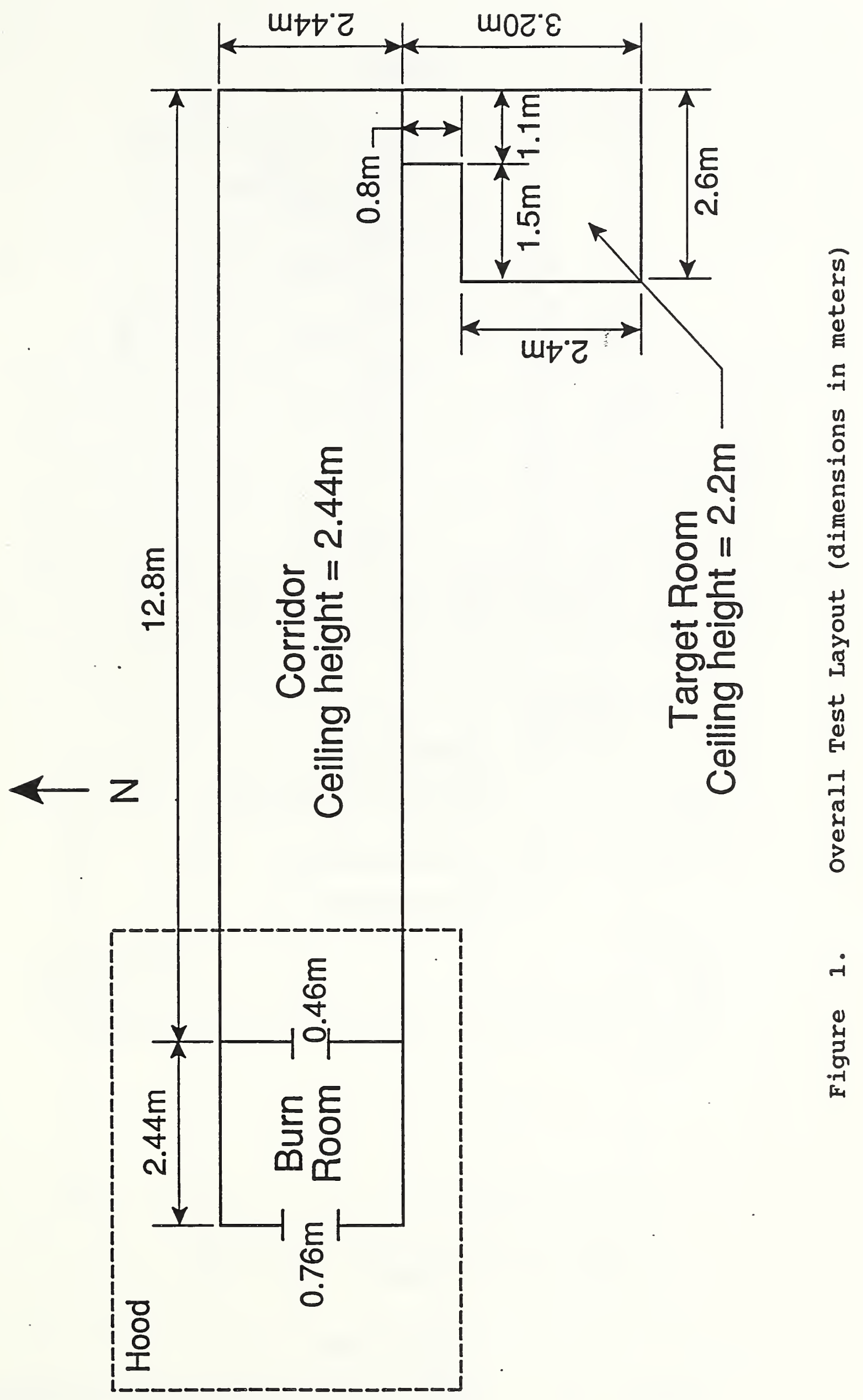




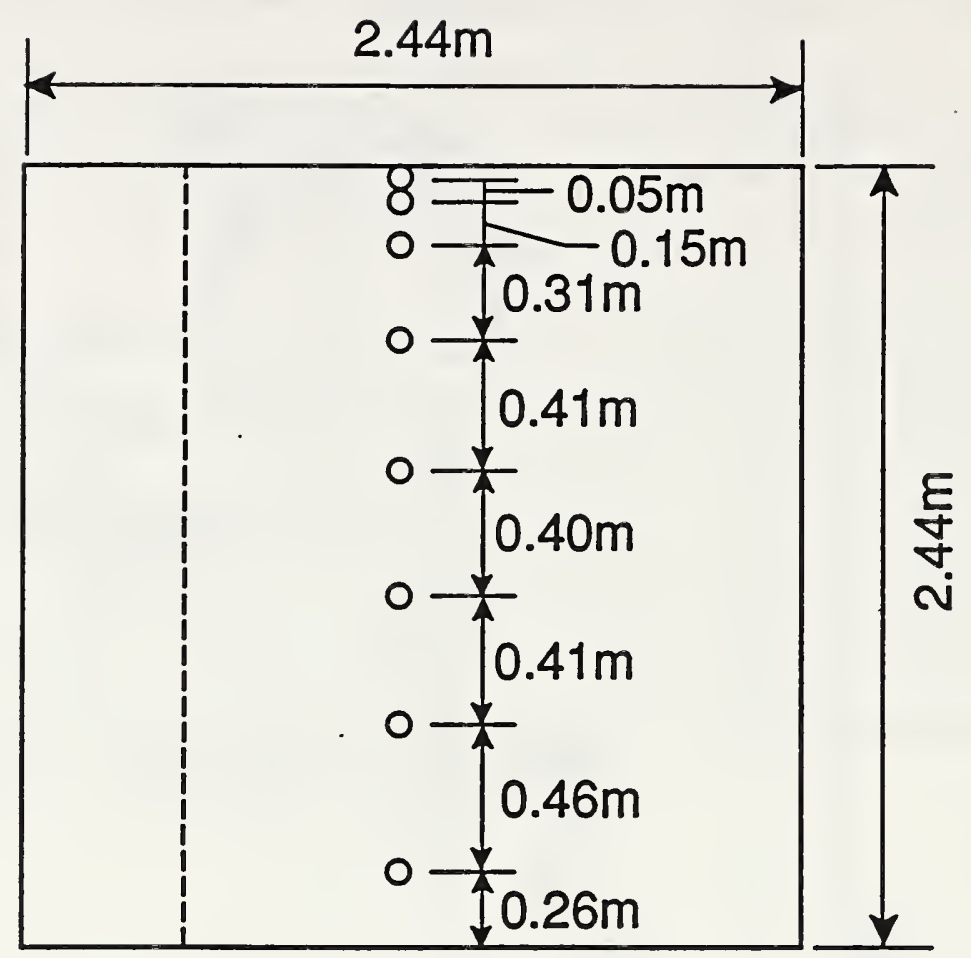

North Wall Elevation View

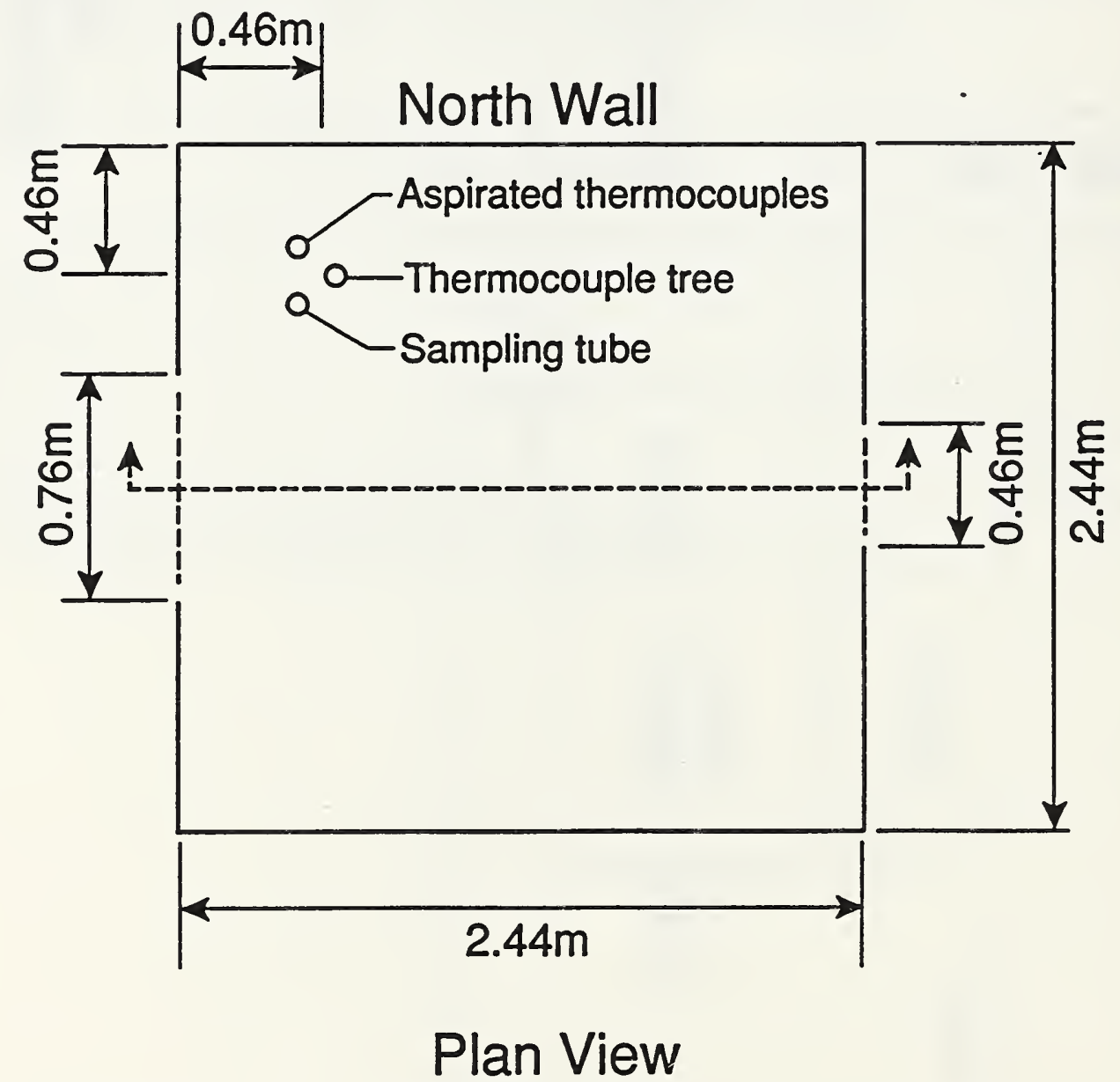

Figure 2. Detailed Burn Room Diagram including Instrument Locations 


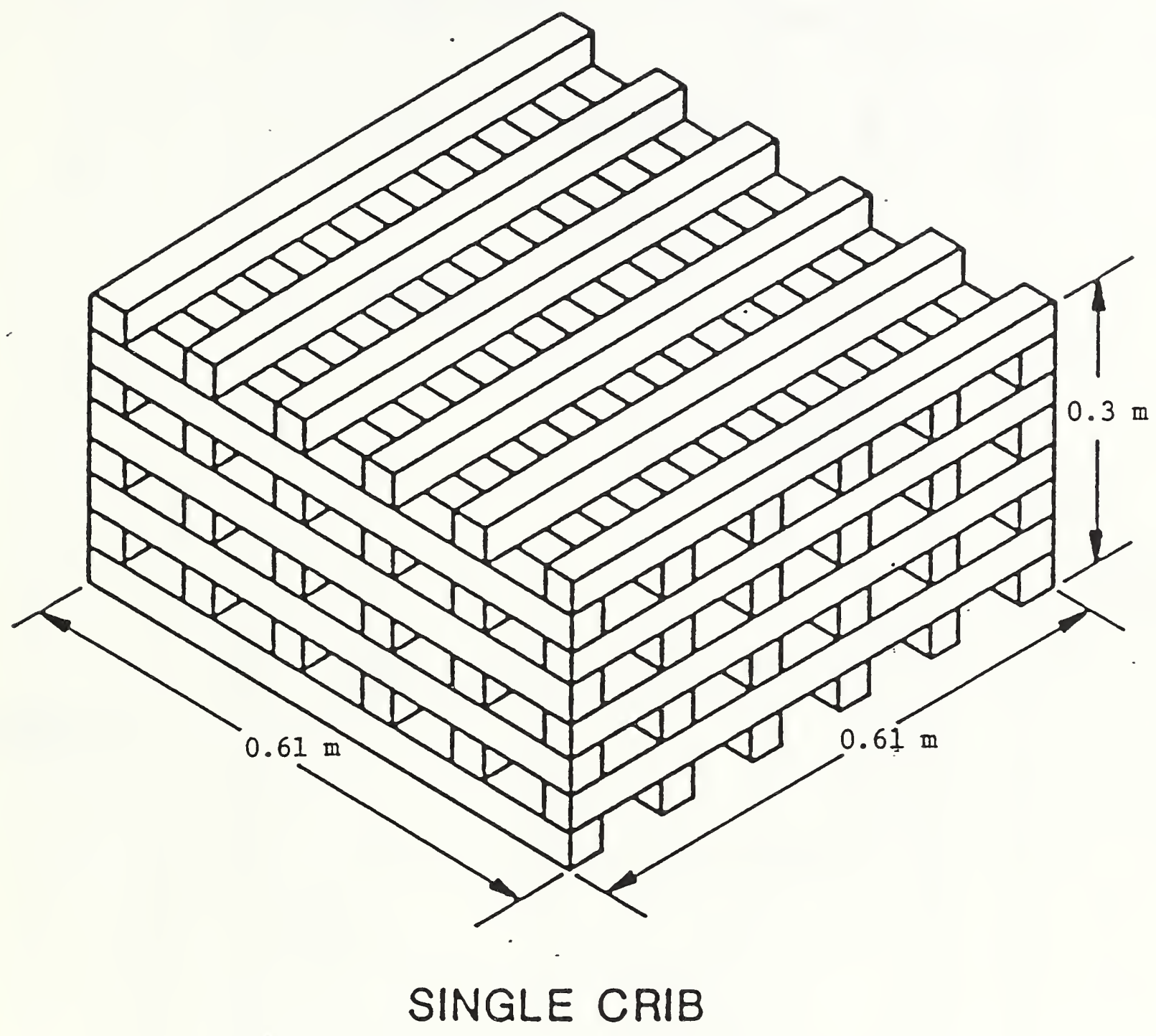

Figure 3. Diagram of Wood Crib used in Test Series 


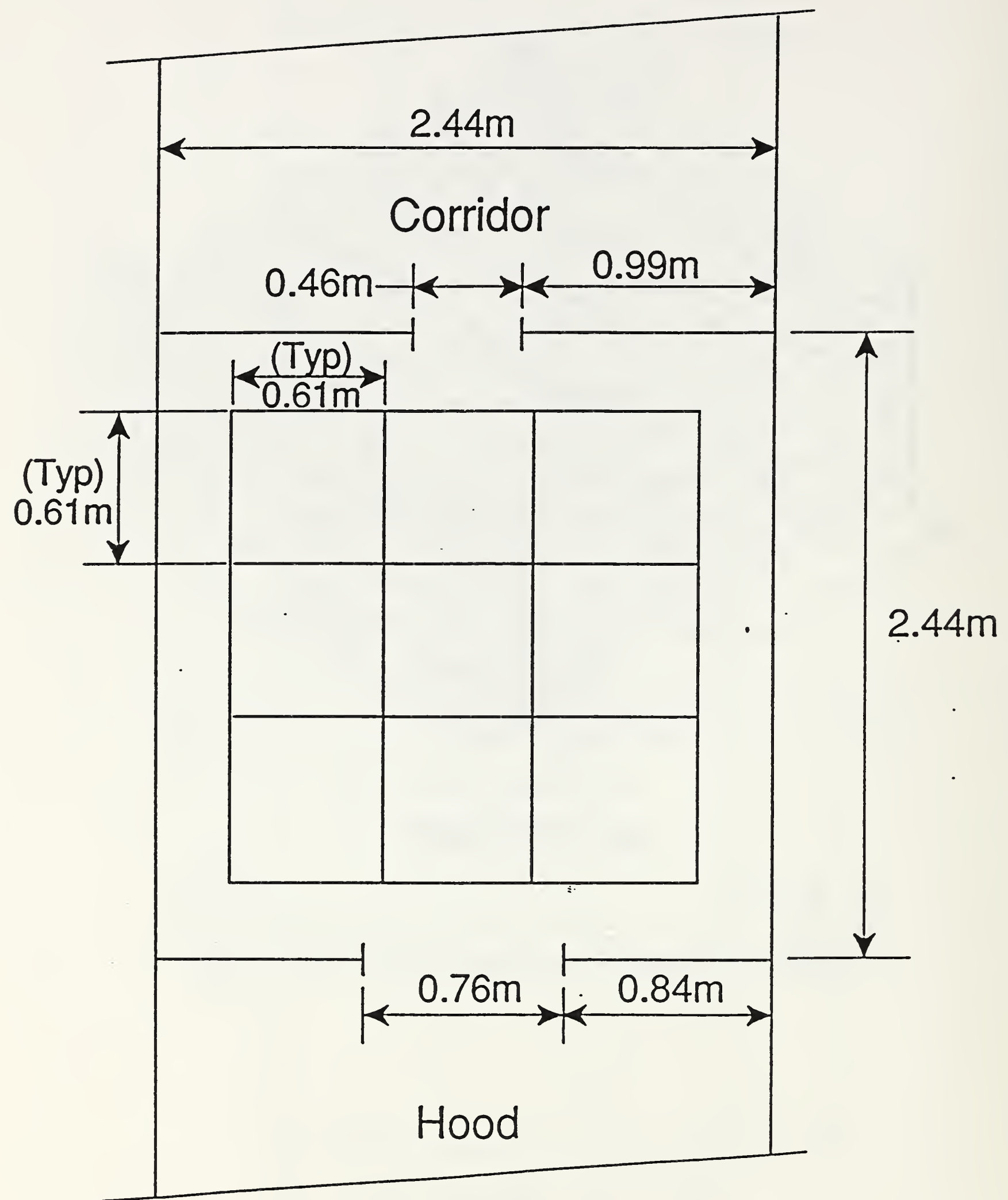

Figure 4. Diagram of Crib Placement in Burn Room (except Accordion Door Test) 


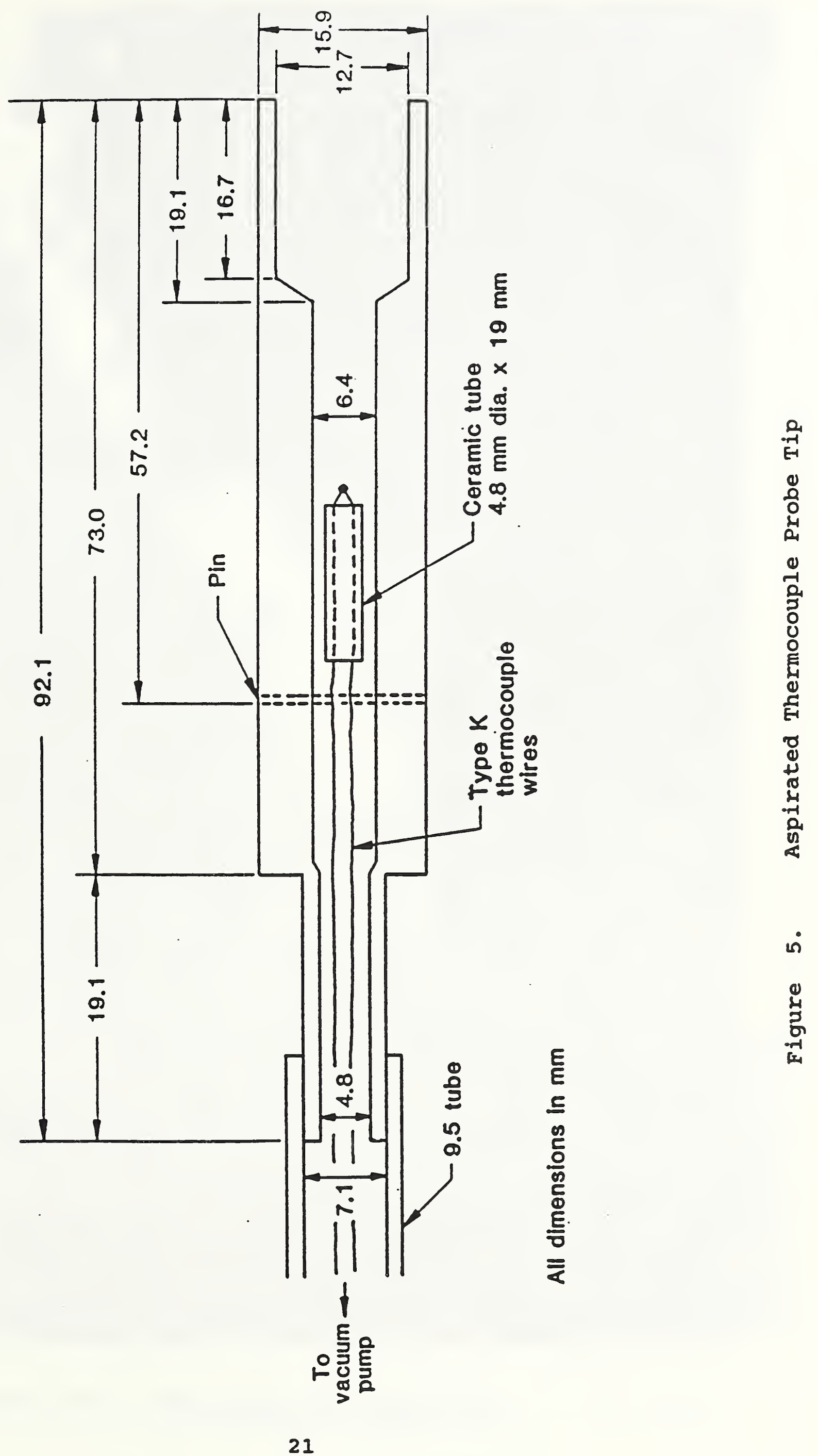




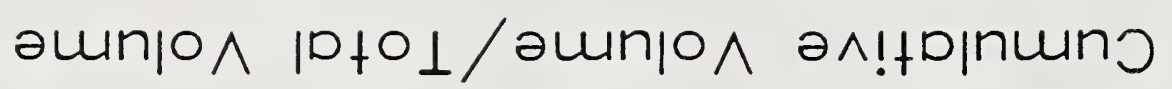

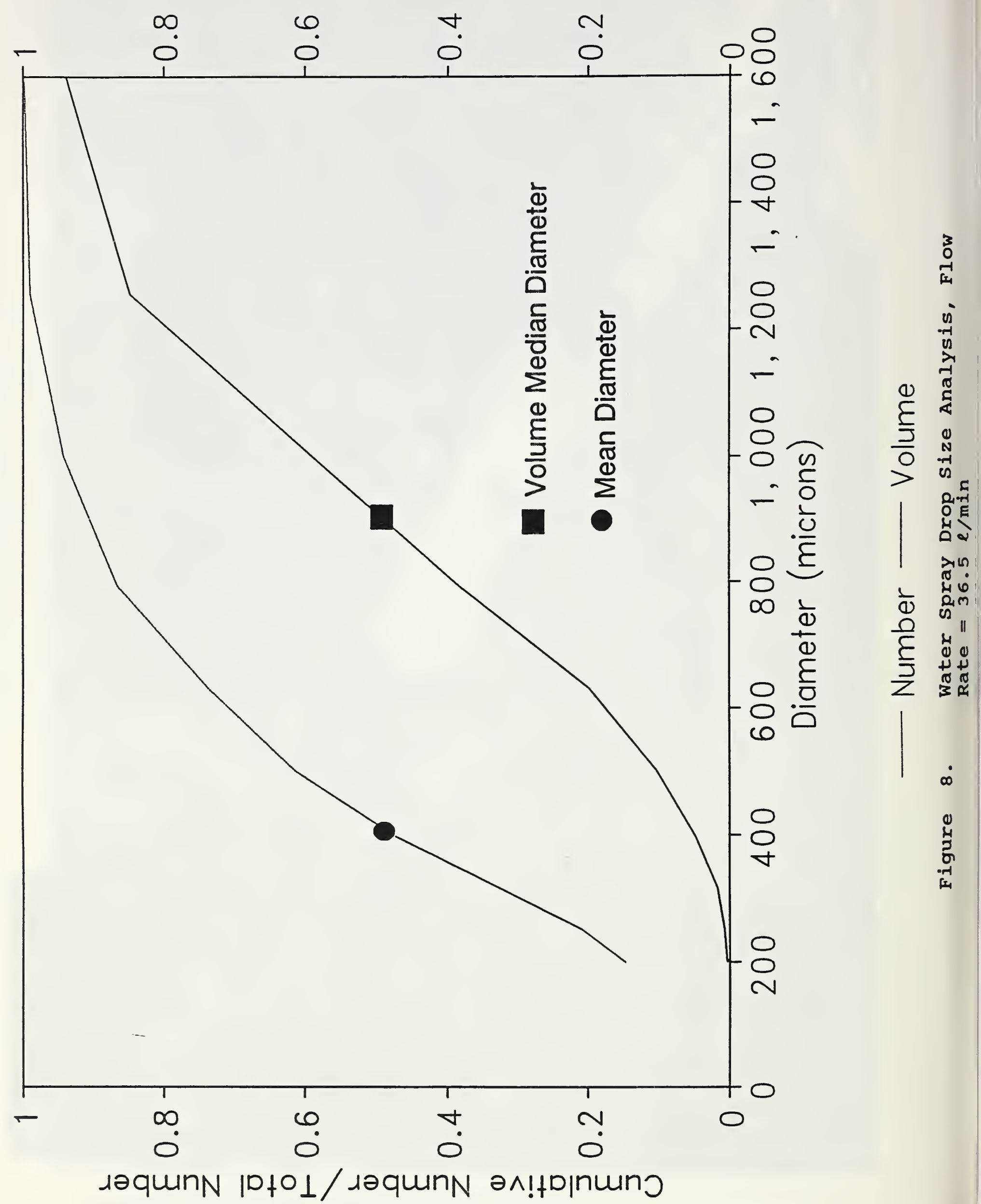




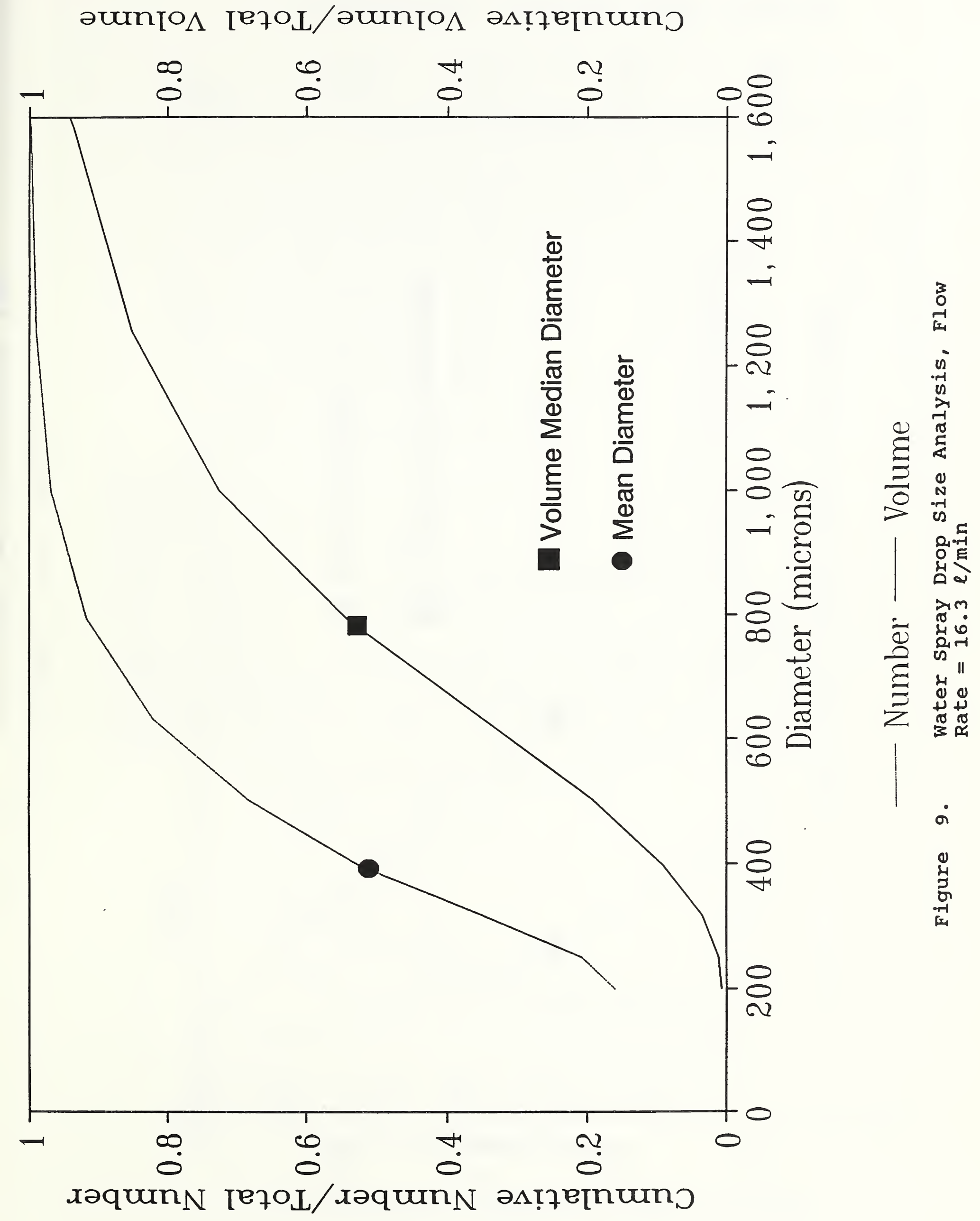




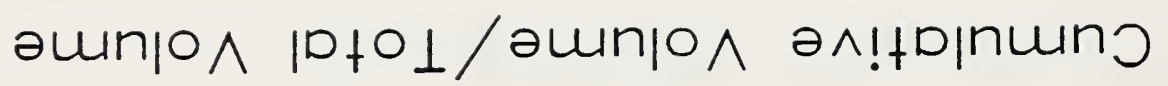

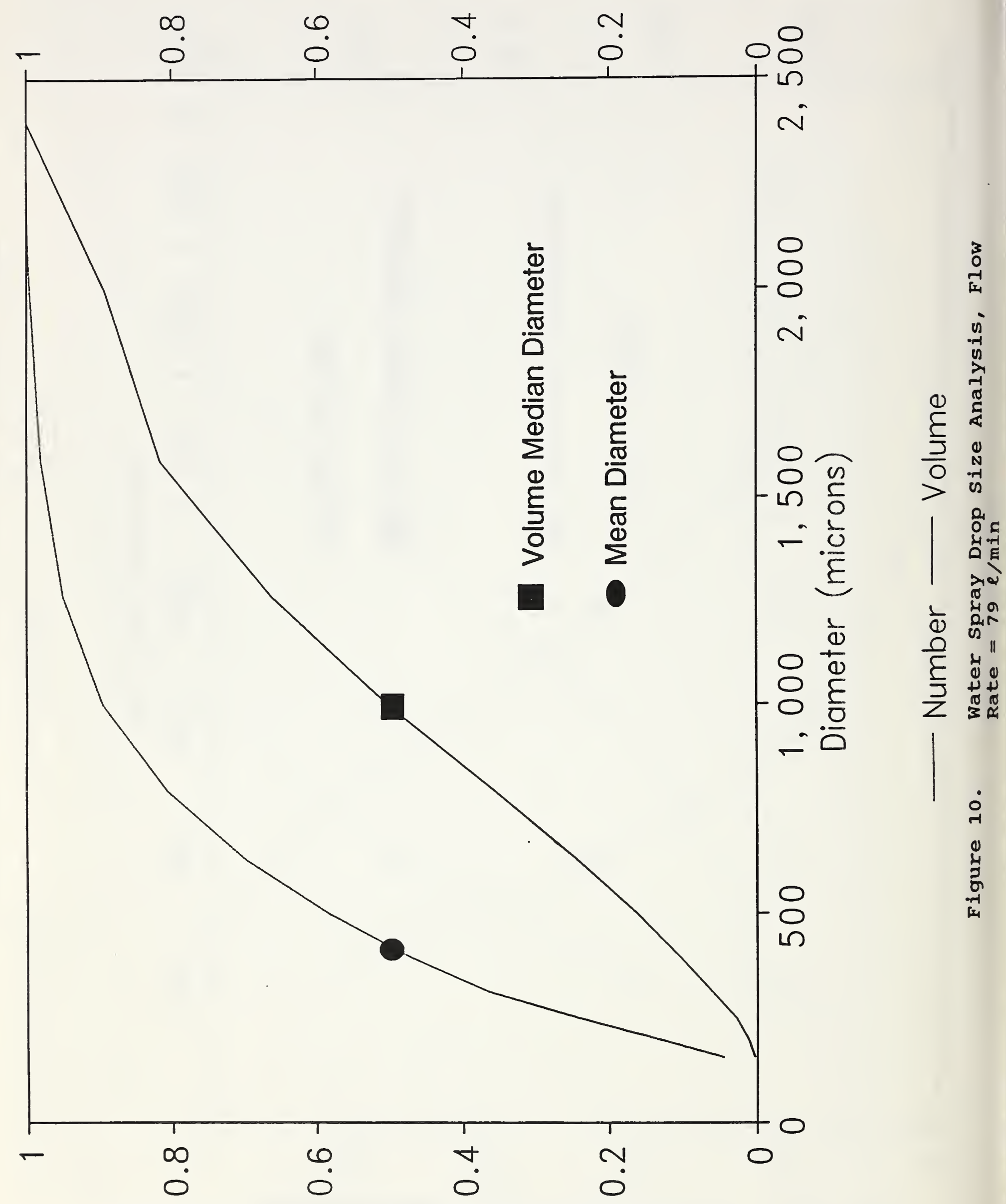

səqunN $\mid D+O \perp /$ səqunN $\partial \wedge !+D \mid n u m b$ 


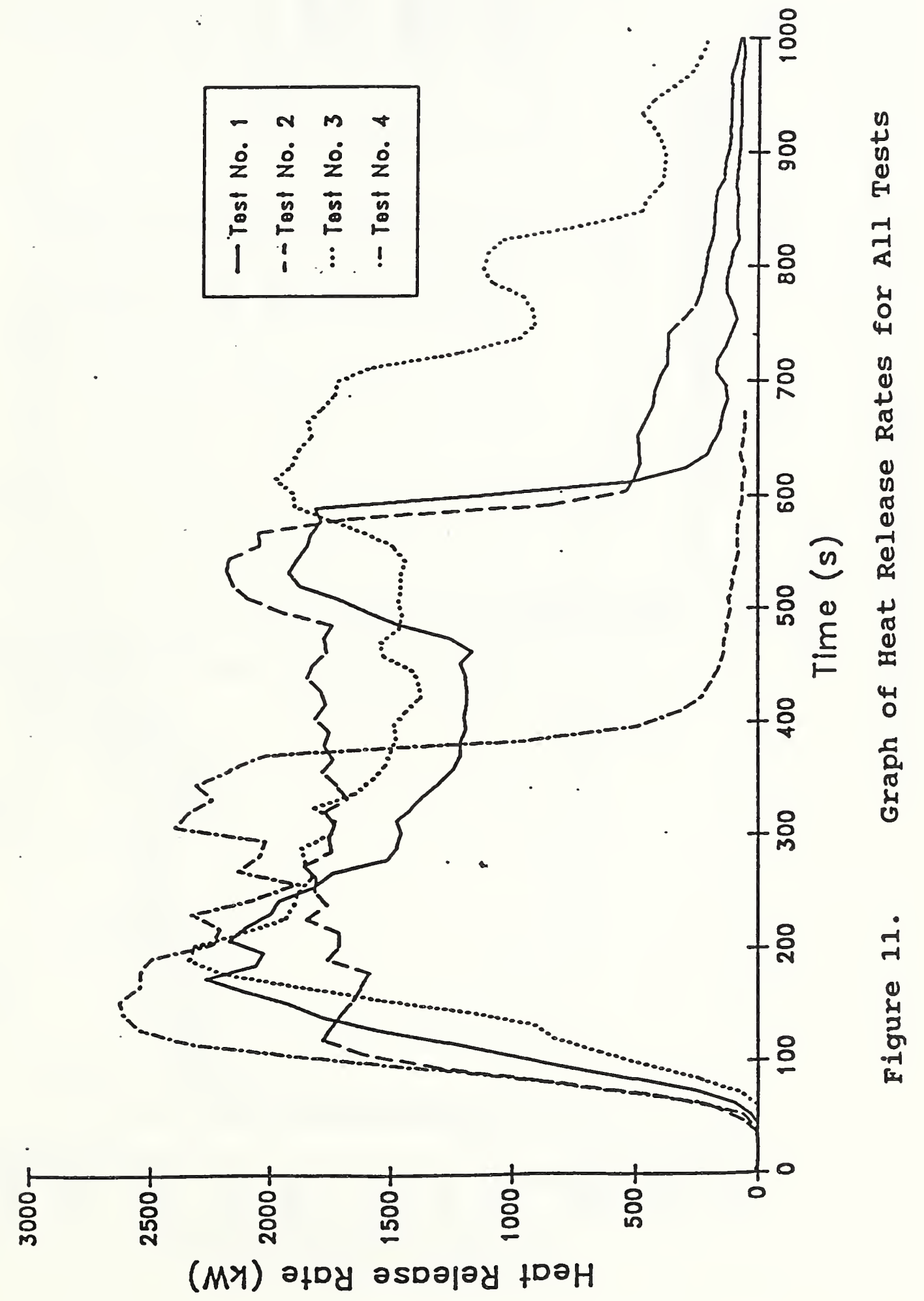




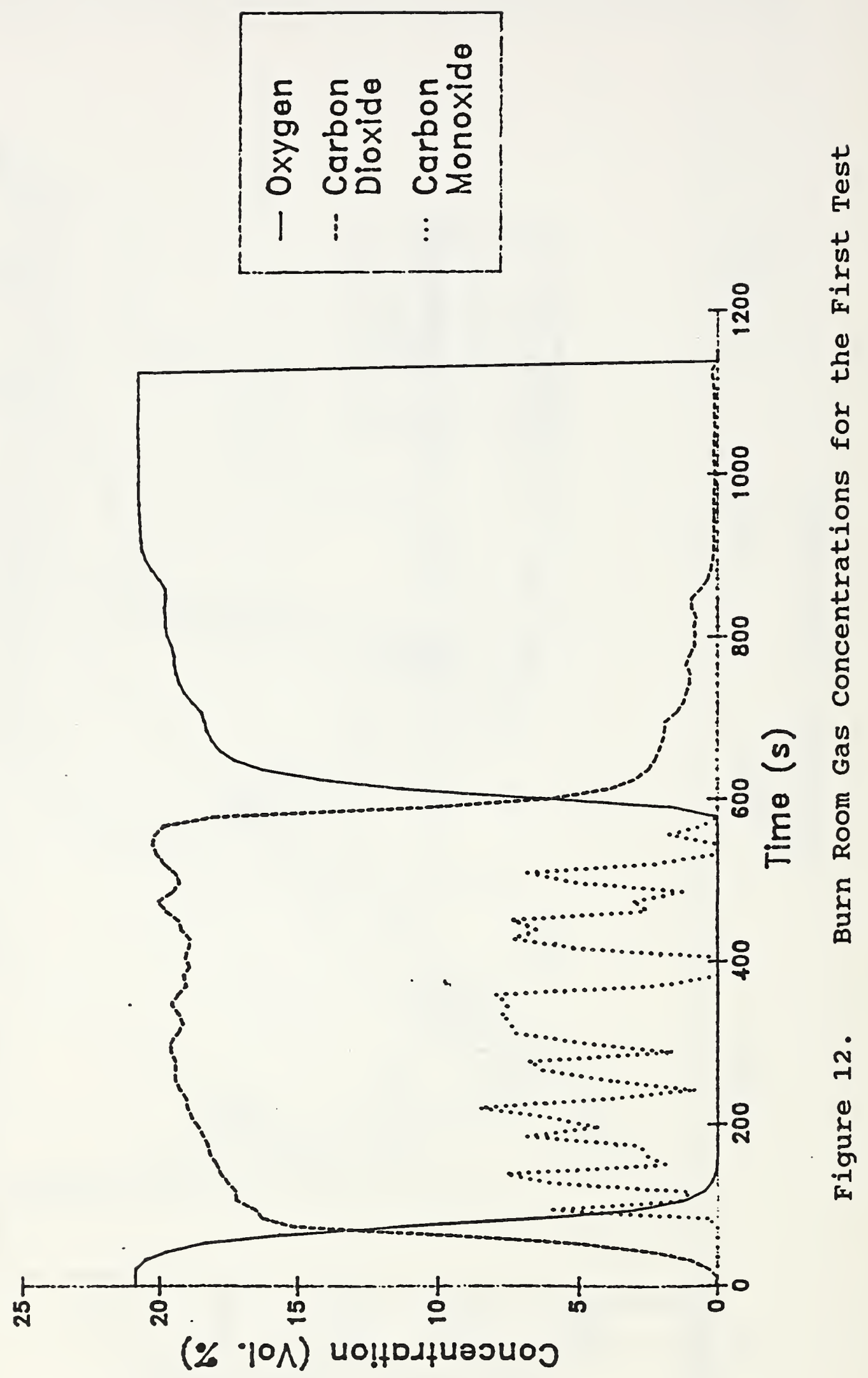




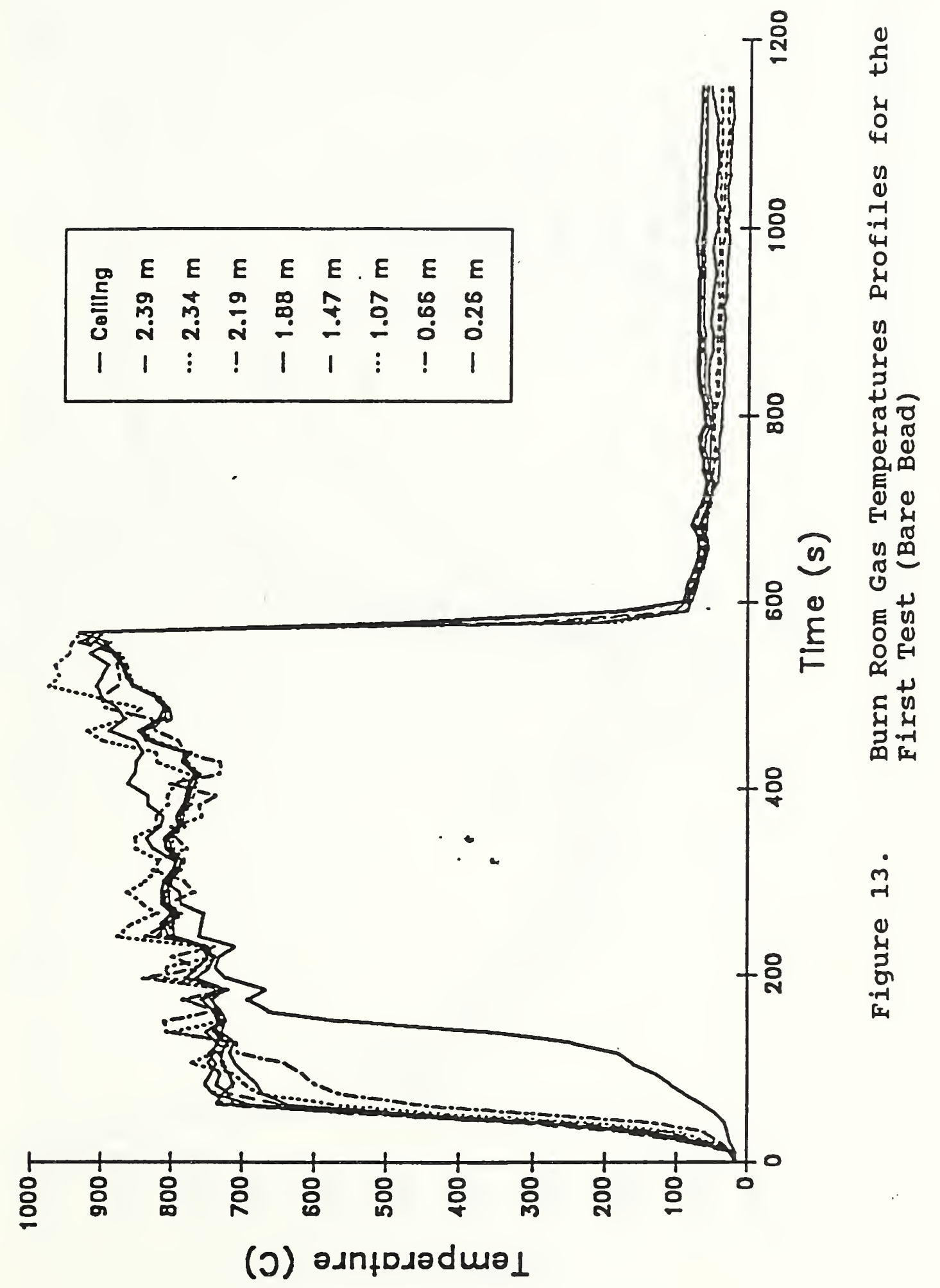




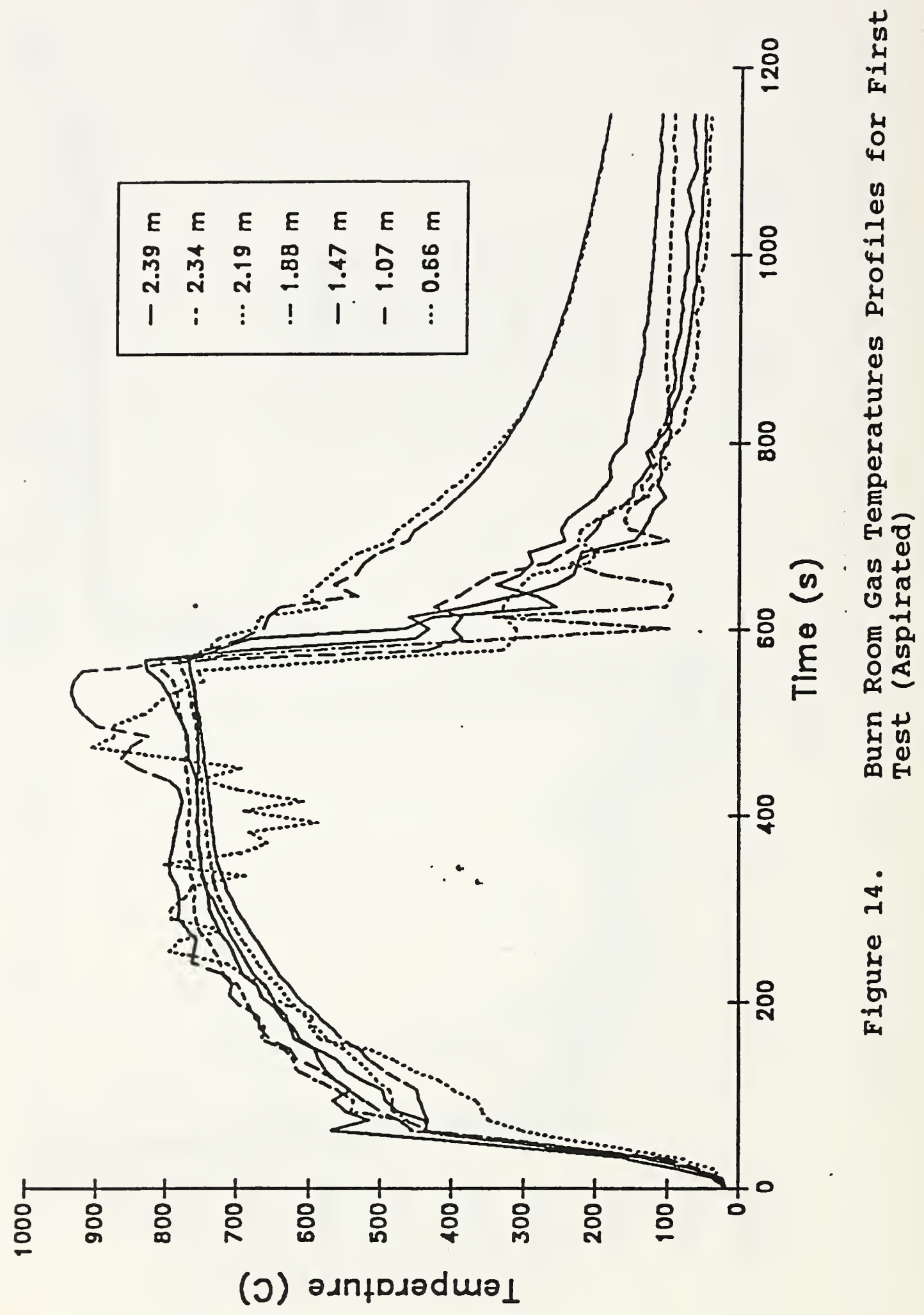




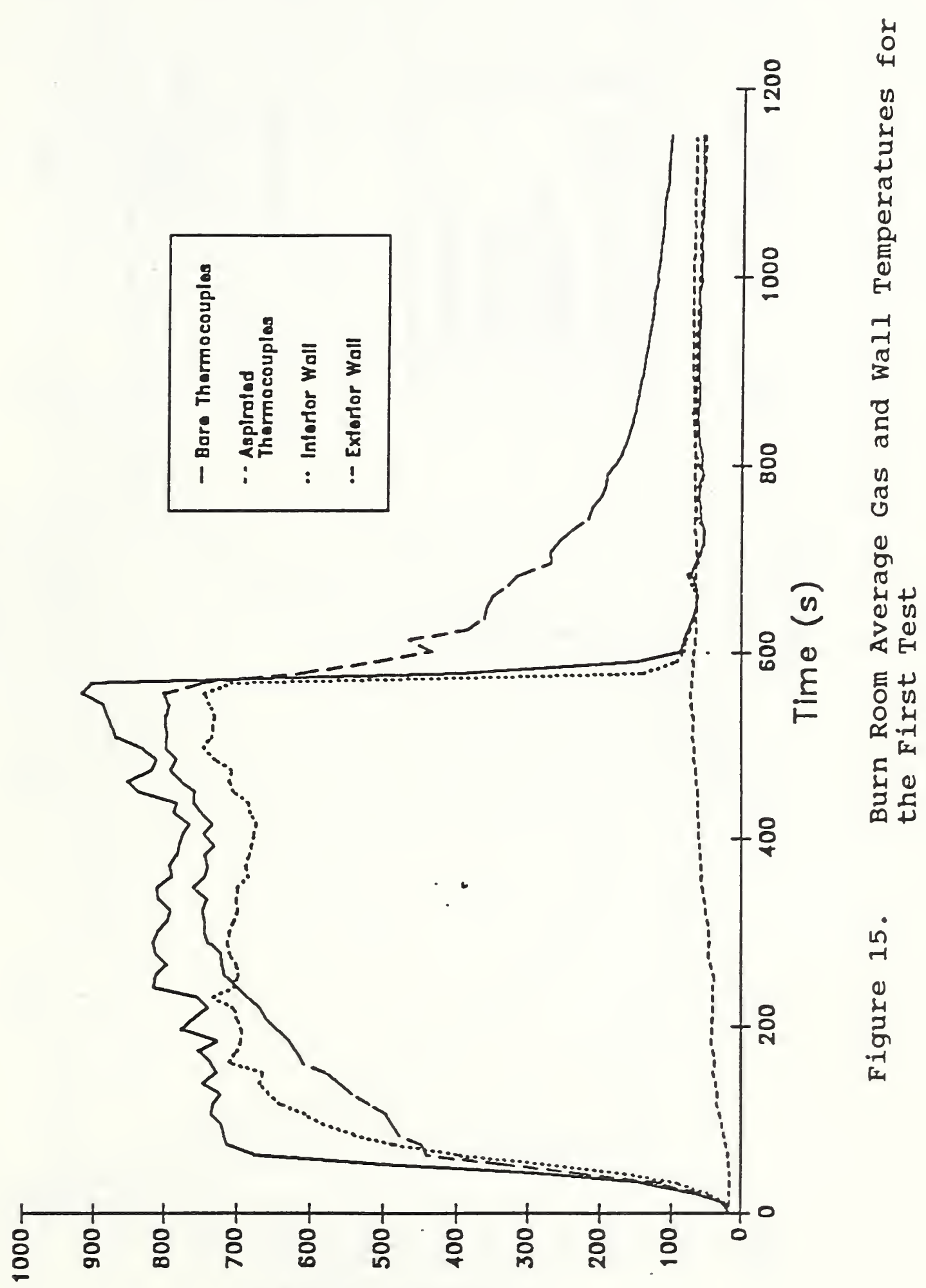

(0) asnfosadual

31 


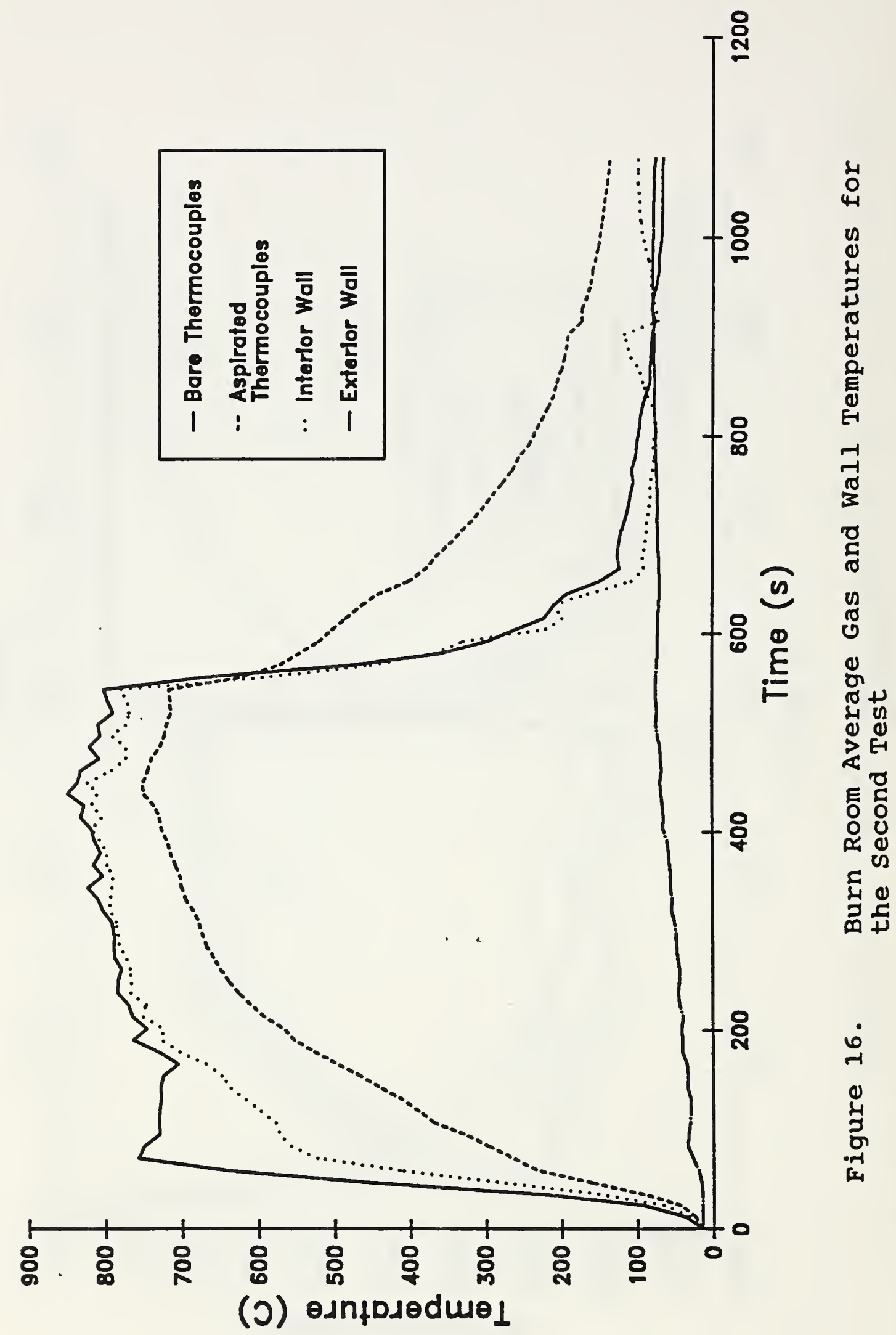




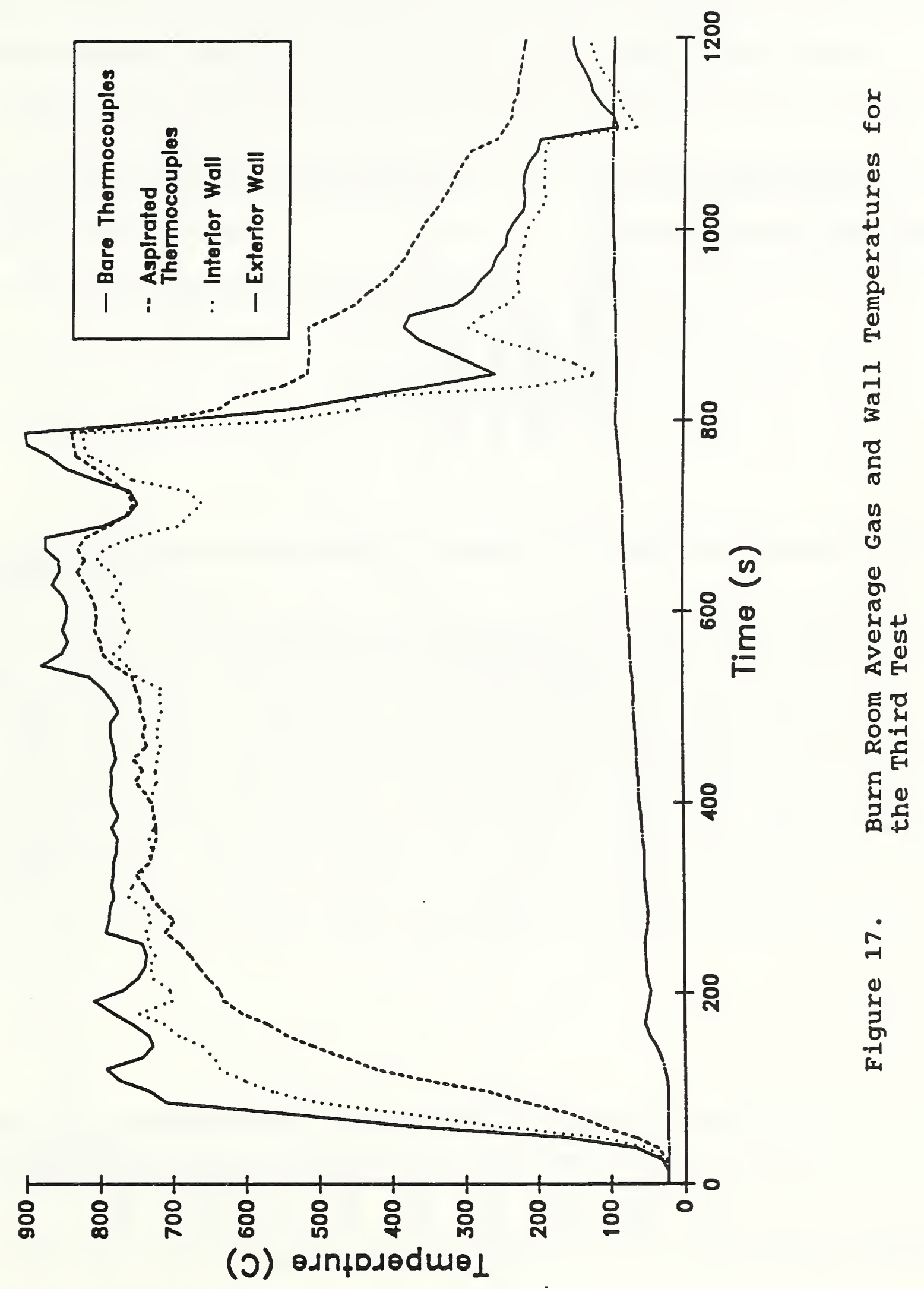




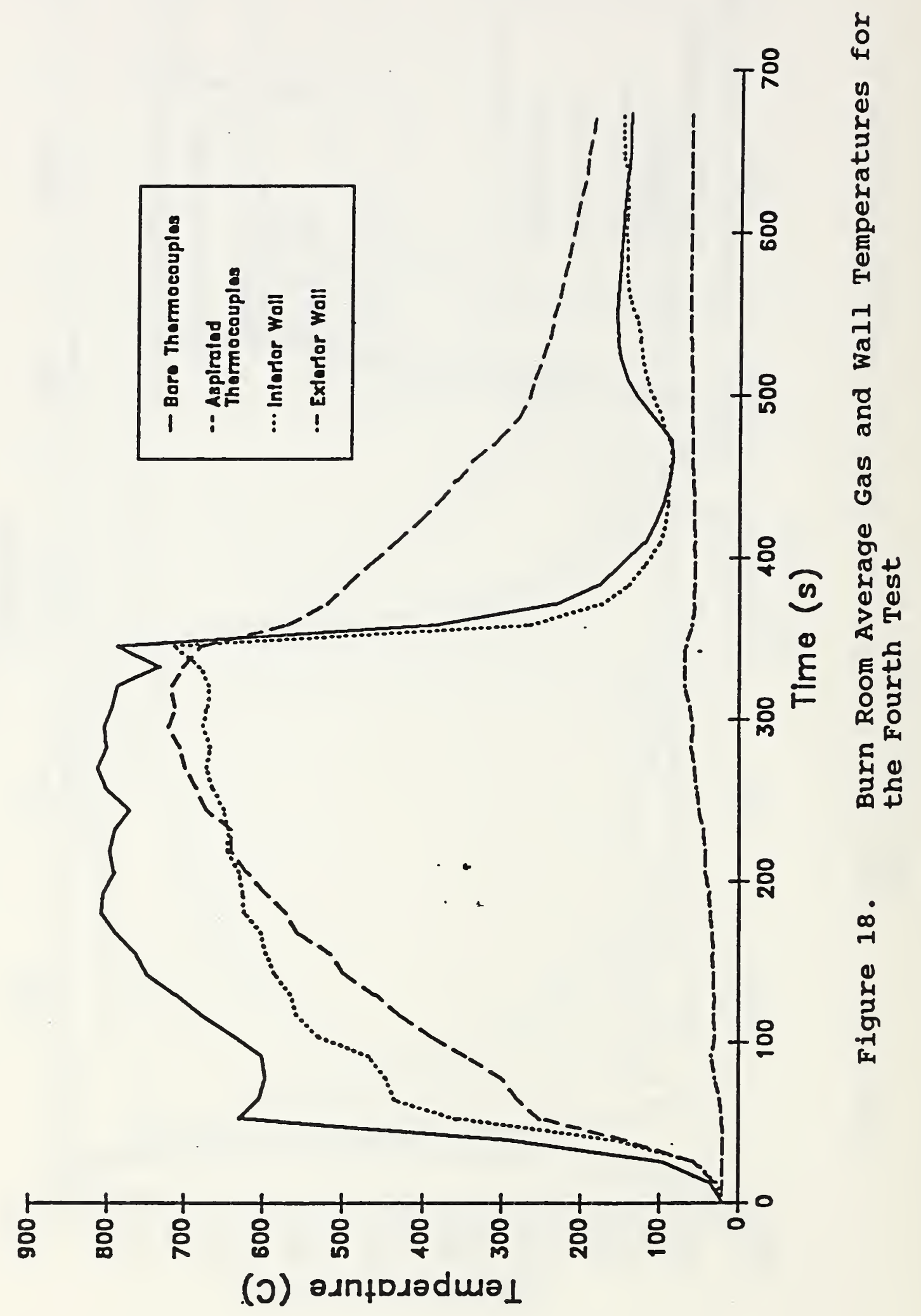




\begin{tabular}{|c|c|c|}
\hline \multirow[t]{3}{*}{$\begin{array}{l}\text { NIST-114A } \\
\text { (REV. 3-90) }\end{array}$} & \multirow{3}{*}{$\begin{array}{l}\text { U.S. DEPARTMENT OF COMMERCE } \\
\text { NATIONAL INSTITUTE OF STANDARDS AND TECHNOLOGY } \\
\text { BIBLIOGRAPHIC DATA SHEET }\end{array}$} & $\begin{array}{l}\text { 1. PUBUCATIOH OR REPORT MUMBER } \\
\text { NISTIR } 4625 \\
\end{array}$ \\
\hline & & 2. PERFORMIMQ ORGANIZATION REPORT HUMBER \\
\hline & & $\begin{array}{l}\text { 3. PUBLLCATION DATE } \\
\text { July } 1991\end{array}$ \\
\hline
\end{tabular}

4. TITLE AND SUBTITLE

Suppression of Post-Flashover Compartment Fires Using Manually Applied Water Sprays

5. AUTHOR(S)

David W. Stroup and David D. Evans

6. PERFORMIMQ ORGANIZATION (IF JOINT OR OTHER THAN NIST, SEE INSTRUCTIONS)

U.S. DEPAATMENT OF COMMERCE

MATIONAL INSTITUTE OF STANDARDS AND TECHNOLOQY

CATHERSBURG, MD 20890

7. CONTRACT/GRANT NUMBER

8. TYPE OF REPORT AND PEAIOD COVERED

9. SPONSORING ORGANIZATION MAME AND COMPLETE ADDRESS (STREET, CITY, STATE, ZP)

Brandforsk

Swedish Fire Research Board and

S-115 87 Stockholm

General Services Administration

Sweden

Public Buildings Service

Office of Real Property Management \& Safety

Washington, DC 20405

10. SUPPLEMENTARY MOTES

11. ABSTRACT (A 200-WORD OR LESS FACTUAL SUMMARY OF MOST SIOMIFICANT INFORMATION. IF DOCUMENT IMCLUDES A SIGMIFICANT BIBLOQRAPHY OR UTERATURE SURVEY, MENTION IT HERE,

A series of four full scale fire tests were conducted to measure the effect of manual fire fighting efforts on post-flashover room fires. One objective of these tests was to generate data for evaluation of computer models of the fire suppression process. The tests were conducted in a room and corridor configuration consisting of a $2.44 \mathrm{~m}$ cube burn room connected to a $12.8 \mathrm{~m}$ long, $2.44 \mathrm{~m}$ wide, and $2.44 \mathrm{~m}$ high corridor. Hose nozzles with different water spray flow rates and medium drop sizes were used in each of the four nominally identical wood crib fires. Gas temperatures, wall surface temperatures and concentrations of oxygen, carbon dioxide, and carbon monoxide were measured in the burn room. Specialized aspirated and shielded thermocouples were used to minimize the effects of the water sprays on gas temperature measurements. This study showed that a water spray flowrate of $36.51 / m i n$ with volume median drop size of 930 microns was just able to control the post-flashover fire, the flowrate of $16.3 \mathrm{l} / \mathrm{min}$ with median volume drop size of 800 microns did not control the $f i r$ fire, while the $79 \mathrm{l}$ /min flowrate with volume median drop size of 1040 microns definitely extinguished the fire.

12 KEY WORDS (6 TO 12 ENTRES; NPHABETCAL ORDER; CAPTTLLE OMLY PAOPEA MAMES; AND SEPARATE KEY WORDS IY SEMICOLONS)

crib tests; drop size measurements; extinguishment; fire fighting; fire fighting equipment;

fire suppression; flashover; nozzles; room fires; sprinkler systems; water sprays

13. AVALAEITY

\begin{tabular}{|l|}
\hline $\mathrm{X}$ \\
\hline \\
\hline
\end{tabular}

Unharmes

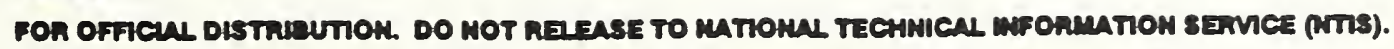

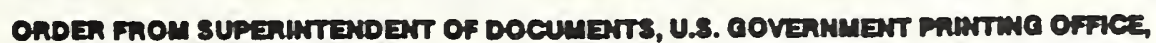
WASHIHATON, DC 20402

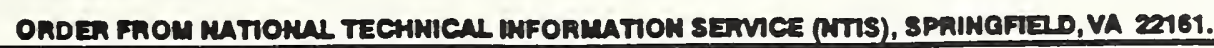

14. MUMBER OF PAINTED PACES

$$
40
$$

15. PMICE

A03 
